九州大学学術情報リポジトリ

Kyushu University Institutional Repository

\title{
Early Identification of Determinate Growth Habit in Lablab Bean (Lablab purpureus (L...) Sweet)
}

Sultana, Nasreen

Laboratory of Horticultural Science, Division of Agricultural Botany, Department of Plant Resources, Graduate School of Bioresource and Bioenvironmental Sciences, Kyushu University

Ozaki, Yukio

Laboratory of horticultural Science, Division of Agricultural Botany, Department of Plant Resources, Faculty of Agriculture, Kyushu University

Okubo, Hiroshi

Laboratory of horticultural Science, Division of Agricultural Botany, Department of Plant Resources, Faculty of Agriculture, Kyushu University

https://doi.org/10.5109/24419

出版情報 : 九州大学大学院農学研究院紀要. 46 (1)，pp.31-38，2001-10-30. Kyushu University バージョン：

権利関係 : 


\title{
Early Identification of Determinate Growth Habit in Lablab Bean (Lablab purpureus (L.) Sweet)
}

\author{
Nasreen SULTANA*, Yukio OZAKI and Hiroshi OKUBO \\ Laboratory of Horticultural Science, Division of Agricultural Botany, Department of Plant \\ Resources, Faculty of Agriculture, Kyushu University, Fukuoka 812-8581, Japan \\ (Received June 13, 2001 and accepted July 11, 2001)
}

\begin{abstract}
Rapid and reliable information for early identification of determinate growth habit is highly desired in the high yielding determinate variety development program. This experiment was conducted to find out some effective morphological markers for the early identification of determinate growth habit of lablab bean. Both determinate and indeterminate plants were grown in $20^{\circ} \mathrm{C}$ and $25^{\circ} \mathrm{C}$ of phytotron in the summer and winter seasons of two consecutive years. The results of this experiment suggest that though the growth and development of lablab bean is influenced by growing environment, still it is possible to identify determinate growth habit within three to 11 weeks after seed sowing at any season. This can make early selection of determinate growth habit possible for variety development program.
\end{abstract}

\section{INTRODUCTION}

Most of the lablab bean cultivars are indeterminate in growth habit, which is one of the major bottlenecks for the commercial production of this crop. Determinate cultivars, on the other hand, have the potential for more extensive cultivation because the plants require no support system, the pods mature uniformly and the crop is amenable to mechanical harvesting, all of which can reduce the cost and labor. The one disadvantages of bush type is that their yields are less than those of normal twining cultivars. Harland (1920) described one determinate variety of lablab bean in West Indies. The growth habit of this variety was controlled by a recessive gene. The second one was reported in India by Shivashankar et al. (1993). This variety was developed after an intensive breeding work. Determinate lablab bean seeds have been introduced to the Laboratory of Horticultural Science, Kyushu University in 1989 from India. The growth habit of this plant changes with sowing time. When the seeds of this accession were sown in mid June and mid July in a plastic house of Kyushu condition, the growth habit changed to indeterminate (Kim et al., 1992). And it was also found from an experiment under controlled conditions that no change of growth habit occurred at any daylength at constant $20^{\circ} \mathrm{C}$ (Kim and Okubo, 1996).

In this context, to develop a new determinate lablab bean with good pod quality requires some effective methods to select the true determinate type. Therefore, the purpose of this study was to find out some morphological markers for early screening of determinate plants from $\mathrm{F}_{2}$ segregating families and next generation, and thus, to save the

\footnotetext{
* Laboratory of Horticultural Science, Division of Agricultural Botany, Department of Plant Resources, Graduate School of Bioresource and Bioenvironmental Sciences, Kyushu University

* Corresponding author
} 
space and labor for maintaining the large segregating families form the process of variety development.

\section{MATERIALS AND METHODS}

'Akabanafujimame', an indeterminate commercial cultivar in Japan and a determinate variety introduced from India were used. For summer planting seeds of both varieties were sown on 7 June and 11 July 1998 in plastic pots ( $12 \mathrm{~cm}$ diameter) containing a mixture of pumice: vermiculite: sand $(1: 1: 1, \mathrm{v} / \mathrm{v} / \mathrm{v})$ and were placed at $20^{\circ} \mathrm{C}$ and $25^{\circ} \mathrm{C}$ in the phytotron, Biotron Institute, Kyushu University. The plants were fed with a $0.1 \%$ solution of compound fertilizer of $\mathrm{OK}-\mathrm{F}-1\left(\mathrm{~N}: \mathrm{P}_{2} \mathrm{O}_{5}: \mathrm{K}_{2} \mathrm{O}=15: 8: 17\right.$. Otsuka Chemical Co., Tokyo). Data were collected weekly on plant height, number of nodes, length of internodes, days to first flowering, position of flower buds on stem and days to maximum flowering. For winter planting seeds of both varieties were sown on 3 November and 5 December 1998 in the similar manner as described for summer. The experiments were repeated in the next year. Twenty plants were used in each replication.

\section{RESULTS}

\section{Morphological characters}

Morphological characters of both determinate and indeterminate plants two weeks after seed sowing are presented in Table 1. Average plant height of the seedlings varied significantly in each growing condition. Both the determinate and indeterminate plants grown at $25^{\circ} \mathrm{C}$ in summer season grew rapidly, and attained a height of 8.5 and $12.5 \mathrm{~cm}$ with a total number of 2.4 and 3.4 nodes, respectively. At this time, lengths of the first and second internodes were 1.5 and $0.5 \mathrm{~cm}$, respectively, in the determinate plants and they were 2.2 and $2.1 \mathrm{~cm}$, respectively, in the indeterminate plants.

Average plant height of the determinate seedlings grown at $20^{\circ} \mathrm{C}$ in summer $(7.7 \mathrm{~cm})$ was significantly lower than that of indeterminate seedlings $(8.7 \mathrm{~cm})$. No difference was

Table 1. Morphological characters ${ }^{z}$ of determinate and indeterminate lablab bean.

\begin{tabular}{lcccccc}
\hline \multirow{2}{*}{ Season } & $\begin{array}{c}\text { Temperature } \\
\left({ }^{\circ} \mathrm{C}\right)\end{array}$ & $\begin{array}{c}\text { Plant } \\
\text { type }\end{array}$ & $\begin{array}{c}\text { Total height } \\
(\mathrm{cm})\end{array}$ & $\begin{array}{c}\text { Total node } \\
\text { number }\end{array}$ & \multicolumn{2}{c}{ Internode length (cm) } \\
\hline \multirow{2}{*}{ Summer } & 25 & $\mathrm{D}$ & $8.5 \mathrm{e}$ & 2.4 & $1 \mathrm{st}$ & 2nd \\
& 20 & $\mathrm{I}$ & $12.5 \mathrm{~h}$ & 3.4 & $2.2 \mathrm{~h}$ & 2.1 \\
& & $\mathrm{D}$ & $7.7 \mathrm{~d}$ & 1 & $1.3 \mathrm{~b}$ & \\
\multirow{3}{*}{ Winter } & 25 & $\mathrm{I}$ & $8.7 \mathrm{f}$ & 1 & $1.6 \mathrm{e}$ & 0.5 \\
& & $\mathrm{D}$ & $7.3 \mathrm{C}$ & 2.7 & $1.4 \mathrm{c}$ & 0.5 \\
& 20 & $\mathrm{I}$ & $9.0 \mathrm{~g}$ & 3 & $1.8 \mathrm{f}$ & 1.0 \\
& & $\mathrm{D}$ & $5.2 \mathrm{a}$ & 1 & $1.0 \mathrm{a}$ & \\
& & $\mathrm{I}$ & $6.1 \mathrm{~b}$ & 1 & $2.0 \mathrm{~g}$ & \\
\hline
\end{tabular}

Measured two weeks after seed sowing.

${ }^{y}$ D; Determinate, In; Indeterminate.

Mean separation within columns by Duncan's multiple range test, $5 \%$. 
observed in total number of nodes. Significant difference of the first internode length contributed to the increase of average length in the indeterminate variety.

Average plant height, total number of nodes and lengths of the first and second internodes in both the determinate and indeterminate varieties, grown at $25^{\circ} \mathrm{C}$ in winter season were significantly different from those in summer season. In this growing condition, the determinate and indeterminate seedlings attained average height of 7.3 and $9.0 \mathrm{~cm}$ with total number of nodes of 2.7 and 3 , respectively. Lengths of the first and second internodes were 1.4 and $0.5 \mathrm{~cm}$ in the determinate plants and 1.8 and $1.0 \mathrm{~cm}$ in the indeterminate plants, respectively.

No differences was observed in total number of nodes in the two weeks seedlings of determinate and indeterminate plants grown at $20^{\circ} \mathrm{C}$ in winter. But significant difference was observed in their plant height $(5.2 \mathrm{~cm}$ in the determinate and $6.1 \mathrm{~cm}$ in the indeterminate plants) and in the first internode length between two types $(1.0 \mathrm{~cm}$ in the determinate and $2.0 \mathrm{~cm}$ in the indeterminate plants).

\section{Flowering on terminal buds}

Flowering percentage on terminal buds in different growing conditions is presented in Fig. 1. The determinate plants grown at $25^{\circ} \mathrm{C}$ in summer season started to flower at the tip of the main stem and branches from seven weeks after seed sowing and $85 \%$ plants flowered within 10 weeks. No flowering was observed in the indeterminate plants by 11 weeks.

The determinate variety started to flower in six weeks after seed sowing and $95 \%$ plants flowered within eight weeks after seed sowing at $20^{\circ} \mathrm{C}$ in summer season. No flowering was observed by 11 weeks in the indeterminate variety.

Flowering at the tip of both the main stem and lateral branches of the determinate variety started from three weeks after seed sowing at $25^{\circ} \mathrm{C}$ in winter season. All the determinate plants flowered within six weeks after seed sowing, whereas no flower bud was observed in the indeterminate variety by 11 weeks after seed sowing.

At $20^{\circ} \mathrm{C}$ in winter season, the determinate plants started to flower in both main stem and lateral branches from six weeks after seed sowing and 100\% plants flowered within ten weeks. No flowering or any lateral branching was observed in the indeterminate accession by 11 weeks.

\section{Plant height}

Average plant height of the determinate accession at the end of flowering is presented in Fig. 2. The indeterminate plants were always more than one meter high irrespective of growing environment (data not shown). The indeterminate plants, grown at $25^{\circ} \mathrm{C}$ in summer season, grew more rapidly than the determinate variety in the same growing conditions and started to be viny from the third week after seed sowing. Internode lengths (third and upwards) of the indeterminate plants increased much more than those of the determinate variety (Fig. 3). No lateral branching was observed in the indeterminate variety by eight weeks after seed sowing.

Lengths of the third and upward internodes of the determinate plants increased more than those of the first and second internodes, but a lesser extent than those of the third and upward internodes of the indeterminate plants at $20^{\circ} \mathrm{C}$ in summer. In some 


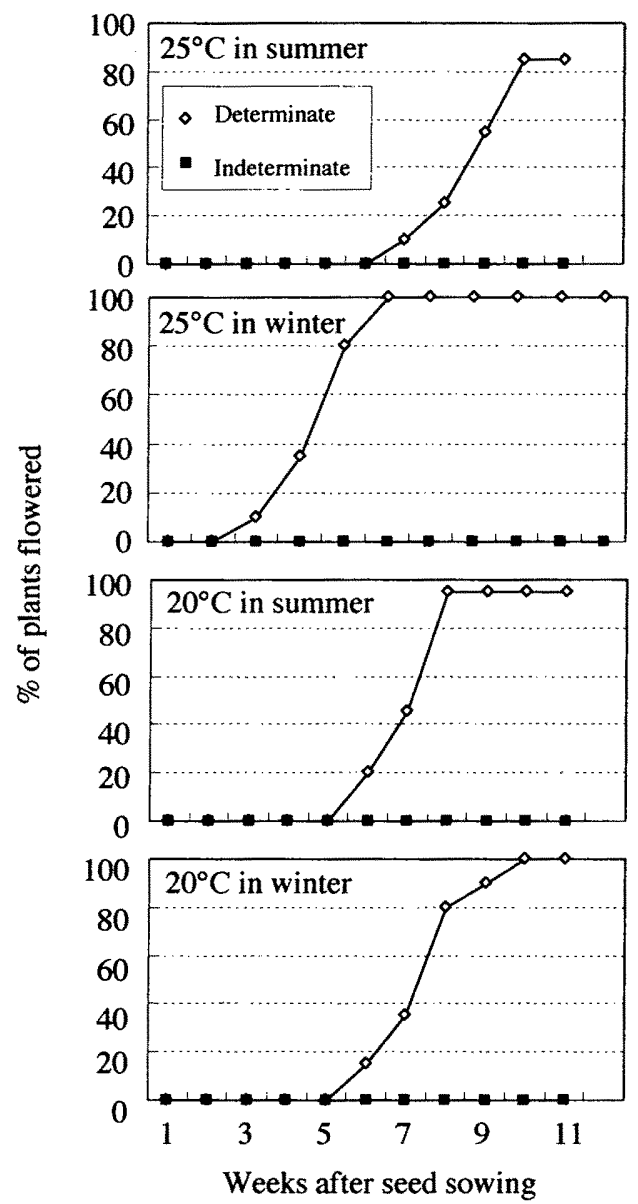

Fig. 1. Percentage of plants flowered on terminal buds. D; determinate, $\mathrm{I}$; indeterminate ('Akabanafujimame').

determinate plants, however, the first or second order lateral branches became viny and attained their lengths longer than the main stem (Fig. 4). In this case, average plant height of the determinate plants was about $80 \mathrm{~cm}$.

The indeterminate plants grown at $20^{\circ} \mathrm{C}$ in summer season started to become viny from 4-5 weeks after seed sowing and no lateral branch observed at the end of 10 weeks. In both types (determinate and indeterminate), the first and second internode lengths were shorter than that of the third internode or upward. But in the determinate plants, increasing rate of elongation was lesser than that of the indeterminate plants. In the determinate plants, lateral branches developed from fourth and/or fifth node but none became viny. At the end of flowering average height of the determinate plants was about $45 \mathrm{~cm}$.

As in summer, the indeterminate plants grown at $25^{\circ} \mathrm{C}$ in winter season started to 


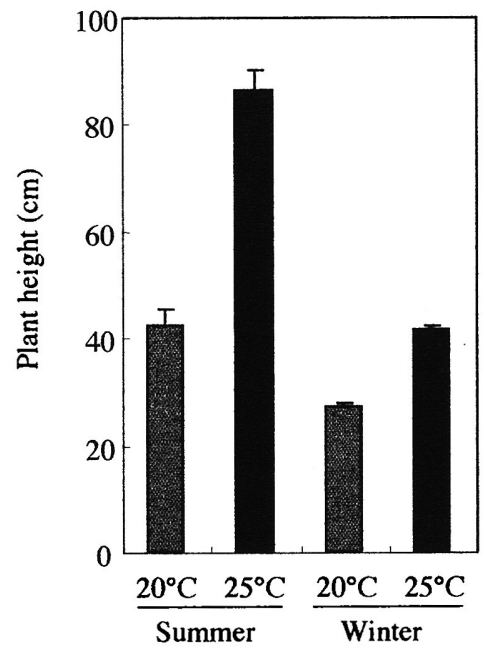

Fig. 2. Plant height of determinate lablab bean grown in summer and winter season at 20 and $25^{\circ} \mathrm{C}$ in the phytotron. The horizontal bars indicate the SE of mean $(n=20)$.

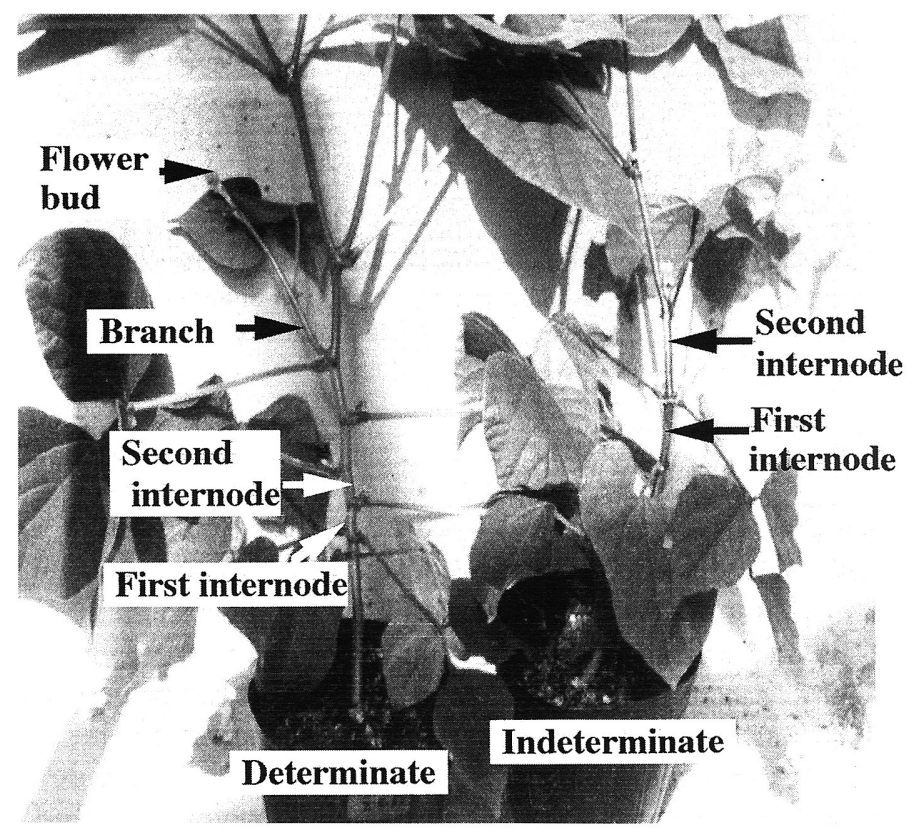

Fig. 3. Determinate and indeterminate plants grown at $25^{\circ} \mathrm{C}$ in summer season (seven weeks after seed sowing). 


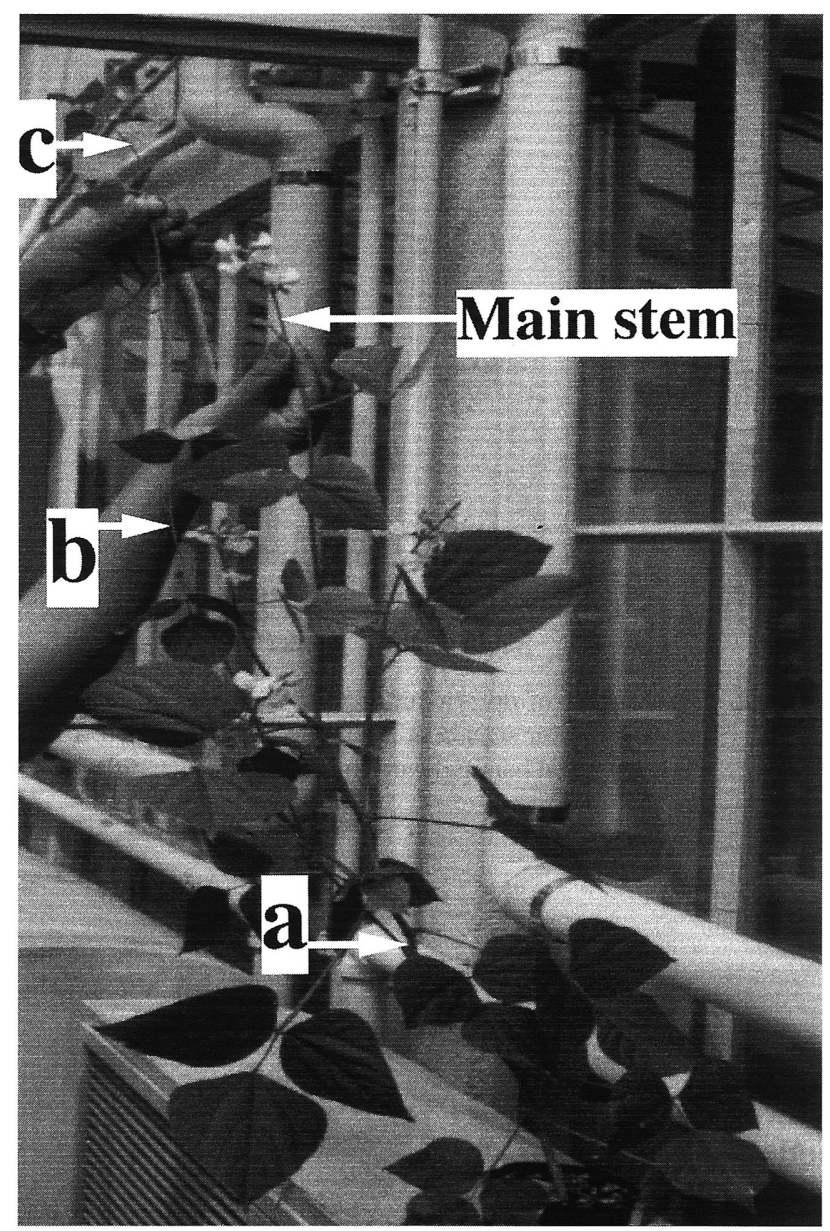

Fig. 4. A determinate plant grown at $25^{\circ} \mathrm{C}$ in summer season. Arrows ( $a, b$ and $c$ ) indicate the first order lateral branch that became viny.

become viny from third weeks after seed sowing and no lateral branch observed till the end of ten weeks. At the end of flowering determinate plants attained average plant height about $40 \mathrm{~cm}$. Lateral branches developed from $4-5$ nodes and no elongation of lateral branches observed in this condition $\left(25^{\circ} \mathrm{C}\right.$ in winter).

At $20^{\circ} \mathrm{C}$ in winter season, the indeterminate plants started to become viny from six weeks after seed sowing and no lateral branches were observed till the end of ten weeks after seed sowing. At the end of flowering average plant height of the determinate plants was about $30 \mathrm{~cm}$ and number of branches was also lower when compared with the other growing environments. No elongation of lateral branches was observed in this condition, too. 


\section{DISCUSSION}

Results of this study confirm the earlier conception of determinate growth habit in lablab bean by Kim and Okubo (1995). They defined that the main stem of determinate lablab bean terminated in an inflorescence or terminated abruptly without flowering. In the present study, all determinate plants flowered in the tip of main stem and branches in short day of winter season irrespective of growing temperature. But $85-95 \%$ plants flowered in summer season. Number of days from seeding to flowering also varied in each growing condition. It became clear from these results that there exists a close relationship between factors controlling stem termination and flower induction in lablab bean. In soybean, there are three gene pairs, which are different from genes conditioning stem termination, known to affect the time of flowering and maturity (Bernard, 1971; Buzzell, 1971; Kilen and Hartwing, 1971).

Harland (1920) defined determinate type of lablab bean as dwarf or bush type. He followed the definition given by Emerson (1916) for French bean and lima bean. According to them the main axis of determinate type terminates in an inflorescence after 4-8 nodes have been developed, secondary branches also terminates in flower cluster. The results obtained in this experiment were also in partial agreement with this concept except in a few cases.

Fifteen percent of the determinate plants did not flower in summer season when grown at $25^{\circ} \mathrm{C}$. The reason probably lies beneath the fact that most of the lablab bean is originally indeterminate (Sultana et al., 2000) and short day plant (Schaaffhausen, 1963; Purseglove, 1977; Duke, 1981), and the expression of the determinate growth habit is restricted in low temperature and short day conditions (Kim, 1994).

Lateral branches of a few determinate plants became viny and contributed to increase the total length of the plant in the same growing condition. This kind of growth habit was described by Piper and Morse (1915) in a collection of 92 accessions of lablab bean. They described that one accession from China was early, not very vigorous and rather bushy. The plant height was about 30 inches but few branches were viny to a length of 3-4 feet. Another accession from Italy was also bushy with a height of 24-30 inches, and some of the branches were viny and were $3-4$ feet long. From these facts, it can be postulated that the determinate growth habit of the present determinate accession most probably came from this kind of bushy type and only in a few cases viny laterals were expressed.

Currence (1932) designated "self pruning type" tomato as determinate. He mentioned that in tomato determinate growth habit is not possible to distinguish from indeterminate in the early stage of growth but after fruits have begun to develop there is a marked difference between two forms. Unlike tomato determinate plants of lablab bean can be identified in early stage (from 3-10 weeks after seed sowing) as it flowers early depending on growing season. Early identification of determinate growth habit in lablab bean is possible under different growing conditions.

\section{REFERENCES}

Bernard, R. L. 1971 Two major genes for time of flowering and maturity in soybeans. Crop Sci., 11: $242-244$

Buzzell, R. I. 1971 Inheritance of soybean flowering response to flourescent-daylength conditions. Can. 
J. Genet. Cytol., 13: 703-707

Currence, T. M. 1932 Linkage relations of growth habit in tomato plants. Proc. Amer. Soc. Hort. Sci., 29: $501-504$

Duke, J. A. 1981 Handbook of Legumes of World Economic Importance. Plenum Press, New York

Emerson, R. W. 1916 A genetic study of plant height on Phaseolus vulgaris. Neb. A. E. S. Research Bull. 7 (cited from Harland, S. C. 1920 Inheritance in Dolichos lablab, L. Part I. Jour. Genet., 10: 219-226)

Harland, S. C. 1920 Inheritance in Dolichos lablab, L. Part I. Jour. Genet., 10: 219-226

Kilen, T. C. and E. E. Hartwing 1971 Inheritance of light-quality sensitive character in soybeans. Crop Sci., 11: 559-561

Kim, S. E. 1994 Studies on the Physiology of Growth Habit in Lablab Bean (Lablab purpureus (L.) Sweet). Ph. D. Thesis, Kyushu University, Fukuoka

Kim, S. E. and H. Okubo 1995 Control of growth habit by grafting between determinate and indeterminate lablab bean (Lablab purpureus) plants. J. Fac. Agr., Kyushu Univ., 39: 229-234

Kim, S. E. and H. Okubo 1996 Control of growth habit in determinate lablab bean (Lablab purpureus) by temperature and photoperiod. Scientia Hortic, 65: 95-105

Kim, S. E., H. Okubo and Y. Kodama 1992 Growth response of dwarf lablab bean (Lablab purpureus

(L.) Sweet) to sowing date and photoperiod. J. Japan. Soc. Hort Sci., 61: 589-594

Piper, C. V. and W. J. Morse 1915 The bonavist, lablab or hyacinth bean. U. S. D. A. Bull., 138: 1-15

Purseglove, J. W. 1977 Tropical Crops. Dicotyledons. Longman, London

Schaaffhausen, R. V. 1963 Dolichos lablab or hyacinth bean: Its use for feed, food and soil improvement. Econ. Bot., 17: 146-153

Shivashankar, G., R. S. Kulkarni, H. E. Shashidhar and D. M. Mahishi 1993 Improvement of field bean. In "Advances in Horticulture Vol. 5. Vegetable Crops" ed. by K. L. Chadha and G. Kalloo, New Delhi, pp. $277-286$

Sultana, N., Y. Ozaki and H. Okubo 2000 The Use of RAPD markers in lablab bean (Lablab purpureus (L.) Sweet) phylogeny. Bull. Inst. Trop. Agr., Kyushu Univ., 23: 45-51 